KALAMATIKA Jurnal Pendidikan Matematika

Volume 2, No. 2, November 2017, hal. 147-158

\title{
PENGGUNAAN MATEMATIKA REALISTIK UNTUK MENINGKATKAN DISPOSISI MATEMATIS SISWA SMP
}

\author{
Vincentia S. Puspitawati ${ }^{1}$ \& Georgius R. Agasi $^{2}$ \\ ${ }^{1}$ Universitas Negeri Yogyakarta \\ vincentpipin2709@gmail.com \\ ${ }^{2}$ Universitas Sanata Dharma Yogyakarta \\ agasi.georgeus.13@gmail.com
}

\begin{abstract}
ABSTRAK
Permasalahan dalam pembelajaran matematika yang sering terjadi adalah pada pengajaran yang seolah-olah matematika jauh dari masalah nyata. Pembelajaran matematika realistik dapat membantu siswa untuk memahami konsep matematika yang bersifat abstrak. Dengan memanfaatkan konteks nyata siswa dapat lebih tertarik dan berminat dalam belajar matematika. Penelitian ini bertujuan untuk melihat pengaruh penerapan pendekatan matematika realistik terhadap disposisi matematis siswa. Penelitian ini merupakan penelitian deskriptif kuantitatif. Subjek penelitian ini adalah siswa kelas VII salah satu SMP Negeri yang terletak di kota Yogyakarta. Subjek dalam penelitian ini sebanyak 35 siswa. Penelitian dilakukan selama 1 bulan. Instrumen dalam penelitian ini adalah angket skala disposisi matematis siswa. Pemberian angket disposisi matematis siswa dilakukan sebelum dan sesudah siswa diberikan perlakuan pembelajaran matematika dengan pendekatan realistik. Hasil angket dianalisis menggunakan statistik deskriptif, dengan melihat rata-rata sebelum dan sesudah diberikan perlakuan serta dikategorisasikan sesuai dengan nilai rata-ratanya. Berdasarkan hasil analisis statistik deskriptif menunjukkan bahwa terjadi peningkatan rata-rata disposisi matematis. Nilai rata-rata sebelum diberikan perlakuan adalah 96,02 dengan kategori sedang kemudian setelah diberikan perlakuan menjadi 109,44 dengan kategori tinggi.
\end{abstract}

Kata Kunci : Matematika Realistik, Disposisi Matematis, Konsep Matematika

\begin{abstract}
The problem of mathematics learning often happens in mathematics teaching that seems far from the real problem. Realistic mathematics learning can help students to understand about mathematics concepts that abstract for them. If the teachers use real context in mathematics learning, students will be more attracted and interested. The purpose of this research is to look at the effect of realistic mathematics learning towards student's mathematical disposition. The method of this research is descriptive quantitative. The subjects were 35 students of SMP N 14 Yogyakarta grade 7 and this research held in one month. The instrument is students' mathematical disposition scale questionnaire. The students fill the questionnaire before and after they are given a treatment. The result of the questionnaire was analyzed using descriptive statistics, by looking at the average before and after treatment and categorized according to the average value. Based on the results of the descriptive statistical analysis showed that an average of students' mathematical disposition has increased. The average value of students in pre-treatment is 96.02 with the medium category and then after treatment is given to the 109.44 with the high category.
\end{abstract}

Keywords: Realistic Mathematics Learning, Mathematical Disposition, Concept of Mathematics 
Format Sitasi: Puspitawati, W. S. \& Agasi, G. R. (2017). Penggunaan Matematika Realistik untuk Meningkatkan Disposisi Matematis Siswa SMP Kelas VII. KALAMATIKA Jurnal Pendidikan Matematika, 2(2), 147-158.

Penyerahan Naskah: 3 Juli 2017 || Revisi: 28 Juli 2017 || Diterima: 4 Agustus 2017

\section{PENDAHULUAN}

Matematika merupakan salah satu mata pelajaran yang penting untuk dipelajari. Terdapat banyak sekali konsep matematika yang ada dari matematika tingkat dasar hingga matematika tingkat menengah atas yang mana konsep-konsep matematika tersebut saling berkaitan satu dengan yang lainnya. Jika siswa dapat memahami konsep matematika dengan baik maka ketika mempelajari konsep matematika berikutnya siswa akan mudah memahaminya. Bahkan konsep matematika dapat kita temukan dalam kehidupan nyata, serta matematika sering kita gunakan dalam aktivitas sehari-hari. Hal tersebut senada dengan pernyataan Freudenthal (1991) bahwa, 'Mathematics for life', and 'mathematics as human activities'. Kehidupan sehari-hari manusia tidak pernah lepas dari peranan matematika.

Terdapat pula tujuan umum dari pembelajaran matematika yang telah ditetapkan Pemerintah dalam Permendiknas Tahun 2006 Nomor 22 tentang Standar Isi, menyatakan bahwa mata pelajaran matematika bertujuan agar peserta didik kemampuan: (1) memahami dan dapat mengaplikasi konsep matematika, (2) menggunakan penalaran, (3) memecahkan masalah, (4) mengkomunikasikan ide/gagasan matematika, (5) memiliki sikap menghargai kegunaan matematika dalam kehidupan. Dari tujuan matematika tersebut jelas bahwa matematika tidak hanya mampu mengembangkan kemampuan kognitif siswa saja, namun juga dapat meningkatkan kemampuan psikomotorik dan afektif siswa.

Tujuan pembelajaran matematika dapat tercapai karena beberapa faktor. Salah satunya adalah peranan guru. Meskipun pada masa sekarang ini guru hanya diminta sebagai fasilitator dalam proses pembelajaran dikelas, tetapi bagaimana guru merencanakan sekaligus membawakan pembelajaran itu penting supaya pembelajaran dikelas menjadi bermakna bagi siswa. Proses pembelajaran yang bersifat mekanistik tentu menjadi sebuah masalah dalam pembelajaran (Sopia \& Wutsqa 2015). Proses pembelajaran yang bersifat mekanistik terjadi jika dalam pembelajaran guru hanya sekedar menjelaskan algoritma yang disertai dengan contoh soal. Dengan cara seperti ini siswa tidak memiliki kesempatan untuk membangun pengetahuannya secara mandiri serta kreativitas siswa dalam berpikir juga terbatas. Siswa hanya menghafal rumus serta 
prosedur dalam menyelesaikan soal matematika tanpa memahami konsep matematika dengan baik.

Pembelajaran matematika realistik merupakan salah satu solusi yang cukup baik untuk mengajak siswa dalam membangun pengetahuan matematikanya. Pembelajaran matematika realistik berorientasi pada proses matematisasi siswa melalui pengalaman sehari hari dan menerapkannya dalam kehidupan sehari-hari. Pembelajaran Matematika Realistik (PMR) merupakan teori pembelajaran matematika yang dikembangkan di negeri Belanda oleh Freudhenthal pada tahun 1973. Menurut Freudhenthal matematika merupakan aktivitas manusia (mathematics as a human activity) dan harus dikaitkan dengan realita (de Lange 1996; Gravemeijer 1994). Menurut Gravemeijer (1994) dalam pembelajaran matematika yang menggunakan pendekatan PMR terdapat tiga prinsip utama yaitu:

1. Penemuan kembali terbimbing (guided reinvention) dan matematisasi progresif (progressive mathematization).

Menurut prinsip reinvention bahwa dalam pembelajaran matematika perlu diupayakan agar siswa mempunyai pengalaman dalam menemukan sendiri berbagai konsep, prinsip atau prosedur, dengan bimbingan guru. Seperti yang dikemukakan oleh Hans Freudenthal bahwa matematika merupakan aktivitas insani dan harus dikaitkan dengan realitas. Dengan demikian, ketika siswa melakukan kegiatan belajar matematika maka dalam dirinya terjadi proses matematisasi. Terdapat dua macam proses matematisasi, yaitu matematisasi horizontal dan matematisasi vertikal. Matematisasi horizontal merupakan proses penalaran dari dunia nyata ke dalam simbol-simbol matematika.Sedangkan matematisasi vertikal merupakan proses penalaran yang terjadi di dalam sistem matematika itu sendiri, misalnya : penemuan cara penyelesaian soal, mengkaitkan antar konsep-konsep matematis atau menerapkan rumusrumus matematika.

2. Fenomenologi didaktis (didactical phenomenology)

Yang dimaksud fenomenologi didaktis adalah para siswa dalam mempelajari konsep-konsep, prinsip-prinsip atau materi lain yang terkait dengan matematika bertolak dari masalah-masalah kontekstual yang mempunyai berbagai kemungkinan solusi, atau setidaknya dari masalah-masalah yang dapat dibayangkan siswa sebagai masalah nyata.

3. Mengembangkan model-model sendiri (self-developed model)

Yang dimaksud mengembangkan model adalah dalam mempelajari konsep-konsep, prinsip-prinsip atau materi lain yang terkait dengan matematika, dengan melalui masalah- 
masalah konteksual, siswa perlu mengembangkan sendiri model-model atau cara-cara menyelesaikan masalah tersebut. Model-model atau cara-cara tersebut dimaksudkan sebagai wahana untuk mengembangkan proses berpikir siswa, dari proses berpikir yang paling dikenal siswa, ke arah proses berpikir yang lebih formal. Jadi dalam pembelajaran guru tidak memberikan informasi atau menjelaskan tentang cara penyelesaian masalah, tetapi siswa sendiri yang menemukan penyelesaian tersebut dengan cara mereka sendiri.

Adapun langkah-langkah pembelajaran matematika dengan pendekatan matematika realistik menurut De Lange meliputi aspek-aspek berikut (Hadi 2005).

1. Pembelajaran dimulai dengan mengajukan masalah (soal) yang 'riil' bagi siswa sesuai dengan pengalaman dan tingkat pengetahuanna, sehingga siswa segera terlibat dalam pembelajaran secara bermakna;

2. Permasalahan yang diberikan tentu harus diarahkan sesuai dengan tujuan yang ingin dicapai dalam pelajaran tersebut;

3. Siswa mengembangkan atau menciptakan model-model simbolik secara informal terhadap masalah yang diajukan;

4. Pengajaran berlangsung secara interaktif; siswa menjelaskan dan memberikan alasan terhadap jawaban yang diberikannya, memahami jawaban dari siswa lain, setuju terhadap jawaban temannya, menyatakan ketidaksetujuan, mencari alternatif penyesuaian yang lain; dan melakukan refleksi terhadap setiap langkah yang ditempuh atau terhadap hasil pelajaran.

Selain mengembangkan kemampuan kognitif siswa, pembelajaran matematika juga harus mampu mengembangkan aspek afektif siswa, salah satunya adalah disposisi matematis siswa. Katz (1993) berpendapat bahwa, "a disposition is a tendency to exhibit frequently, consciously, and voluntary a pattern of behaviour that is directed to a broad goal”. Artinya bahwa disposisi adalah kecendurngan untuk berperilaku secara sadar, teratur, dan sukarela untuk mencapai suatu tujuan tertentu. Jika dikaitkan dengan matematika, maka disposisi matematis adalah kecenderungan siswa untuk berpikir dan bertindak secara positif terhadap matematika.

Kilpatrick, Swafford, \& Findell (2001) menamakan disposisi matematis sebagai productive disposition (disposisi produktif). Disposisi produktif adalah kecenderungan untuk melihat matematika sebagai sesuatu yang logis, berguna, dan bermanfaat, ditambah dengan kepercayaan dalam ketekunan dan kegigihan diri sendiri. Siswa yang memiliki disposisi yang tinggi maka akan lebih gigih, tekun, dan berminat dalam mengeksplorasi hal-hal yang baru sehingga memungkinkan siswa tersebut memiliki pengetahuan yang 
lebih dibandingkan dengan siswa yang tidak menunjukkan perilaku demikian (Mahmudi 2010).

NCTM (1989) menyatakan bahwa penilai disposisi matematis siswa dapat dilihat dari: (1) percaya diri dalam menggunakan matematika untuk memecahkan masalah, mengkomunikasikan ide-ide serta dalam memberi alasan; (2) fleksibel dalam mengeksplorasi ide-ide matematis dan mencoba berbagai metode alternatif untuk memecahkan masalah; (3) gigih dan ulet dalam menyelesaikan tugas-tugas matematika; (4) ketertarikan, keingintahuan dan kemampuan untuk menemukan dalam pembelajaran; (5) kecenderungan untuk melakukan refleksi diri terhadap cara berpikir dan kinerjanya sendiri; (6) menghargai aplikasi matematika dalam berbagai situasi yang timbul dari ilmu lainnya dan pengalaman sehari-hari, (7) mengapresiasi peranan matematika sebagai budaya dan menilainya sebagai suatu alat dan bahasa.

Lebih lanjut lagi Kilpatrick, Swafford, \& Findell (2001) berpendapat bahwa disposisi produktif mengacu pada kecenderungan memandang matematika sebagai sesuatu yang dapat dipahami, merasakan matematika sebagai sesuatu yang berguna, meyakini usaha yang tekun dan ulet dalam mempelajari matematika, dan melakukan tindakan sebagai siswa yang efektif.

Dalam penelitian ini indikator yang digunakan dalam mengukur disposisi matematis siswa meliputi: (1) percaya diri; (2) kegigihan/ketekunan; (3) minat dan keingintahuan; (4) fleksibel dalam berpikir; (4) merefleksikan hasil berpikir dan hasil kinerja; (5) mengapresiasi peranan matematika dan mengaplikasikan dalam kehidupan sehari-hari

Berdasarkan fakta-fakta diatas peneliti merumuskan pertanyaan penelitian, apakah penerapan pembelajaran matematika realistik dapat meningkatkan disposisi matematis siswa.

\section{METODE PENELITIAN}

Penelitian ini merupakan penelitian kuantitatif dengan pendekatan deskriptif. Metode Penelitian Kuantitatif merupakan metode penelitian yang berlandaskan pada filsafat positivisme, digunakan untuk meneliti pada populasi atau sampel tertentu, pengumpulan data menggunakan instrumen penelitian, analisis data bersifat kuantitatif/statistik, dengan tujuan untuk menguji hipotesis yang telah ditetapkan (Sugiyono 2012). Sedangkan penelitian deskriptif yaitu, penelitian yang dilakukan untuk mengetahui nilai variabel mandiri, baik satu variabel atau lebih (independen) tanpa 
membuat perbandingan, atau menghubungkan dengan variabel yang lain (Sugiyono 2012). Berdasarkan teori tersebut, dapat disimpulkan bahwa penelitian deskriptif kuantitatif merupakan analisis data yang diperoleh dari sampel populasi penelitian sesuai dengan menggunakan metode statistik yang sesuai.

Bagian metode penelitian ini menguraikan langkah-langkah penyelesaian masalah. Uraikan dengan jelas prosedur penelitian yang dilakukan. Metode yang dipilih agar disesuaikan dengan jenis penelitiannya. Sebagai contoh penelitian eksperimen, desain penelitian, pengambilan populasi dan sampel serta prosedur pelaksanaan penelitian harus jelas.

\section{Subjek Penelitian}

Populasi dalam penelitian ini adalah siswa kelas VII SMP Negeri 14 Yogyakarta tahun ajaran 2016/2017 yang terdiri dari 4 kelas pararel. Sampel dipilih secara acak sehingga terpilih satu kelas dari 4 kelas pararel.

\section{Prosedur Penelitian}

Penelitian ini diawali dengan memberikan angket awal. Angket awal diberikan siswa sebelum diberikan perlakuan dan digunakan untuk mengetahui disposisi matematis awal siswa. Tahap selanjutnya adalah dengan memberikan perlakuan berupa pembelajaran matematika realistik. Tahap terakhir adalah dengan memberikan angket ke-II yang bertujuan untuk mengetahui pengaruh dari perlakuan yang diberikan siswa.

\section{Instrumen Penelitian}

Instrumen yang digunakan dalam penelitian ini instrumen nontes berupa angket disposisi matematis siswa. Angket yang digunakan dalam penelitian ini adalah untuk mengetahui tingkat/skala disposisi matematis siswa terhadap matematika. Angket ini memuat 30 butir pernyataan yang terdiri dari 17 butir pernyataan positif dan 13 pernyataan negatif. Angket disusun dalam skala Likert, yang terdiri dari 5 macam alternatif jawaban.

Sebelum diberikan untuk siswa pada kelas sampel, angket diujicobakan pada kelas Ujicoba. Data hasil angket disposisi matematis pada siswa kelas ujicoba digunakan untuk mencari kevalidan instrumen. Validitas konstruk menunjukkan sejauh mana tes mengukur konstruk teoritik yang hendak diukur (Allen dan Yen 1979) dengan melakukan analisis faktor dengan bantuan sofware SPSS 21.0 for window. Kriteria yang digunakan adalah nilai Kaiser-Meyer-Olkin Measure of Sampling Adequacy (KMO). Apabila nilai KMO < 
0,5, maka item-item tersebut dikeluarkan secara bertahap dari yang paling kecil sampai memperoleh nilai $K M O>0,5$.

Reliabilitas suatu instrumen nontes berkaitan dengan keajegan instrumen nontes tersebut. Jika suatu instrumen memiliki kemampuan untuk menghasilkan pengukuran yang ajeg dan tidak berubah-ubah jika digunakan secara berulang-ulang pada sasaran yang sama, dengan menggunakan alat ukur yang sama dan prosedur yang sama, maka dapat dikatakan instrumen tersebut reliabel. Dalam menghitung koefisien reliabilitas angket menggunakan rumus Alpha Cronbach (Ebel 1986). Setelah diperoleh koefisien reliabilitas instrumen menggunakan rumus Alpha Cronbach, dilakukan penghitungan SEM.

\section{Teknik Analisis Data}

Data tentang disposisi matematis siswa diperoleh dengan menggunakan instrumen nontes yang berbentuk checklist dengan skala Likert. Skor berada pada rentang 30 sampai dengan 150. Untuk menentukan kriteria hasil pengukuran digunakan klasifikasi berdasarkan rata-rata ideal (Mi) dan standar deviasi ideal (Si) dengan konversi data kuantitatif ke kualitatif dengan skala lima (Azwar 2011). Selanjutnya dihitung persentasenya untuk masing-masing kategori, yaitu sangat tinggi, tinggi, sedang, rendah, dan sangat rendah.

\section{HASIL DAN PEMBAHASAN}

Pemberian perlakuan berupa pembelajaran matematika realistik dilakukan sebanyak enam kali pertemuan. Pembelajaran matematika realistik pada penelitian ini menggunakan benda konkrit untuk membantu siswa dalam memahami konsep matematika, serta masalah yang diberikan oleh siswa adalah masalah yang ditemukan dalam kehidupan sehari-hari. Hal tersebut dilakukan supaya siswa dapat dengan mudah membayangkan masalah yang tersirat dalam soal dan dapat memodelkan masalah tersebut menjadi sebuah kalimat matematika. Dengan memanfaatkan benda konkrit yang ada disekitar siswa serta dengan menggunakan masalah yang dapat ditemukan dalam kehidupan sehari-hari itu pula siswa menjadi lebih berminat dalam mengikuti pembelajaran. Keingintahuan serta kepercayaan diri siswa meningkat dalam proses pemecahan masalah. Selama proses pembelajaranpun siswa diberi kesempatan untuk dapat menemukan serta memberi contoh masalah dalam kehidupan sehar-hari yang berkaitan dengan materi yang sedang dipelajari. 


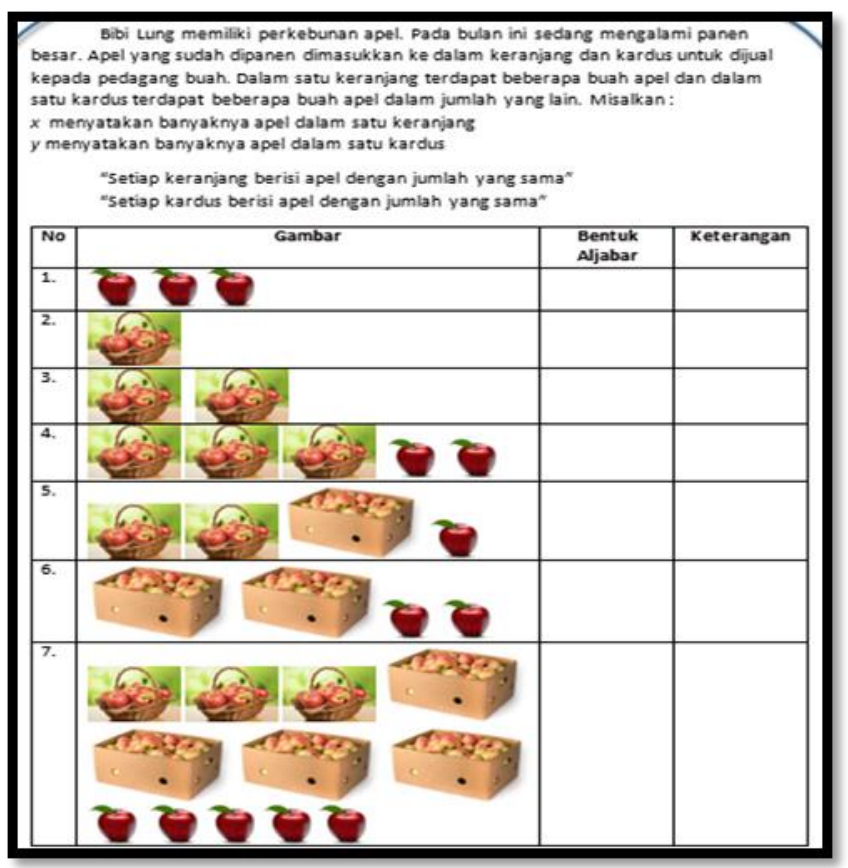

Gambar 1. Contoh soal realistik yang diberikan

1. Seorang petani mempunyai sebidang tanah berbentuk persegi panjang. Lebar tanah tersebut $6 \mathrm{~m}$ lebih pendek daripada panjangnya. Jika keliling tanah $60 \mathrm{~m}$, buatlah model matematika dari masalah tersebut! Penyelesaian:

Gambar 2. Contoh masalah realistik yang diberikan

Disposisi matematis siswa diukur dengan menggunakan angket yang terdiri dari 30 pernyataan berupa pernyataan positif dan negatif. Skor minimal 30 dan maksimal adalah 150. Pada tabel 1 dibawah ini disajikan kisi-kisi angket disposisi matematis dari salah satu indikator yang digunakan dalam penelitian ini.

Tabel 1. Kisi-kisi angket disposisi matematis

\begin{tabular}{llc}
\hline Indikator & \multicolumn{1}{c}{ Pernyataan } & $\begin{array}{c}\text { Jenis } \\
\text { Pernyataan }\end{array}$ \\
\hline percaya diri & Saya yakin dapat memperoleh nilai yang baik dalam matematika & + \\
& Saya yakin dapat memahami materi matematika dengan baik & + \\
& Saya yakin dapat menyelesaikan semua masalah matematika & + \\
& Saya malu jika bertanya kepada guru tentang kesulitan yang saya alami & - \\
& Saya takut untuk mempresentasikan hasil jawaban di depan kelas & - \\
\hline
\end{tabular}

Angket disposisi matematis diberikan oleh siswa sebelum dan sesudah siswa mendapat perlakuan. Data hasil pengukuran disposisi matematis siswa disajikan pada tabel 1. 
Tabel 2. Skor Disposisi Matematis

\begin{tabular}{lcc}
\hline Ukuran Statistik & Sebelum perlakuan & Setelah perlakuan \\
\hline Banyak Siswa & 32 & 34 \\
Rata-rata & 96,03 & 109,44 \\
Simpangan Baku & 33,10 & 22,25 \\
\hline
\end{tabular}

Berdasarkan tabel 2, rata-rata disposisi matematis siswa sebelum diberikan perlakuan adalah 96,03. Rata-rata tersebut berada pada interval skor $80<X \leq 100$, yaitu termasuk pada kategori sedang. Sedangkan pada hasil rata-rata skor disposisi matematis siswa setelah diberikan perlakuan adalah 109,44. Rata-rata skor disposisi matematis siswa setelah diberikan perlakuan berada pada interval skor $100<X \leq 120$, yaitu termasuk pada kategori tinggi.

Frekuensi dan persentase banyak Siswa ada setiap kategori disposisi matematis dihitung berdasarkan rentang skor yang telah ditentukan sebelumnya. Distribusi frekuensi dan persentase disposisi matematis siswa sebelum dan sesudah diberikan perlakuan disajikan pada tabel 3 .

Tabel 3. Distribusi Frekuensi dan Persentase Disposisi Matematis

\begin{tabular}{lccccc}
\hline \multirow{2}{*}{ Interval Skor } & \multirow{2}{*}{ Kategori } & \multicolumn{2}{c}{ Sebelum perlakuan } & \multicolumn{2}{c}{ Setelah perlakuan } \\
\cline { 3 - 5 } & & $\mathrm{F}$ & $\%$ & $\mathrm{~F}$ & $\%$ \\
\hline $\mathrm{X}>120$ & Sangat Tinggi & 4 & $12,50 \%$ & 7 & $20,6 \%$ \\
\hline $100<\mathrm{X} \leq 120$ & Tinggi & 12 & $37,50 \%$ & 23 & $67,7 \%$ \\
\hline $80<\mathrm{X} \leq 100$ & Sedang & 13 & $40,6 \%$ & 4 & $11,8 \%$ \\
\hline $60<\mathrm{X} \leq 80$ & Rendah & 3 & $9,4 \%$ & 0 & $0,00 \%$ \\
\hline $\mathrm{X} \leq 60$ & Sangat Rendah & 0 & 0,00 & 0 & $0,00 \%$ \\
\hline
\end{tabular}

Data pada tabel 3 menunjukkan bahwa sebelum diberi perlakuan, 4 siswa $(12,50 \%)$ berada pada kategori sangat tinggi, 12 siswa (37,50\%) pada kategori tinggi, 13 siswa $(40,6 \%)$ pada kategori sedang, dan 3 siswa $(9,4 \%)$ berada pada kategori rendah. Data setelah diberikan perlakuan terjadi pergeseran kategori. Kategori sangat tinggi menjadi 20,6\%, kategori tinggi 67,7\%, dan sisanya 11,8\% kategori sedang. Melalui tabel 2, jelas bahwa terjadi peningkatan persentase siswa pada kategori tinggi dan sangat tinggi pada saat sebelum diberikan perlakuan dan setelah diberikan perlakuan.

\section{KESIMPULAN}

Penggunaan pendekatan matematika realistik dalam pembelajaran matematika dapat meningkatkan disposisi matematis siswa. Hal tersebut tampak dari rata-rata disposisi matematis siswa yang meningkat setelah melaksanakan pembelajaran matematika dengan pendekatan realistik. Terdapat pula peningkatan persentase jumlah siswa pada kategori sangat tinggi dan kategori tinggi. Terdapat perbedaan tindakan siswa dalam menyelesaikan 
tugas-tugas berupa LKS. Siswa menjadi lebih berminat dan tekun dalam menyelesaikan tugas-tugas pada LKS. Pendekatan matematika realistik dapat memberikan pengaruh yang lebih baik dalam meningkatkan disposisi matematis siswa.

\section{REKOMENDASI}

Untuk penelitian selanjutnya bisa dilakukan pengembangan dengan membandingkan dua sekolah dengan situasi yang berbeda namun memiliki kondisi awal berupa kategori disposisi matematis yang sama. Apakah dengan menerapkan pendekatan matematika realistik akan mengalami perubahan pada kondisi akhir pada masing-masing sekolah. Selain itu dapat dilihat juga apakah terdapat kesamaan atau perbedaan pada proses belajarnya.

\section{REFERENSI}

Allen, M.J. \& Yen, W.M. (1979). Introduction to Measurement Theory. Monterey, CA.: Brooks/Cole Publishing Company.

Azwar, S. (2011). Reliabilitas dan validitas. Yogyakarta: Pustaka Pelajar.

Ebel, R. L., \& Frisbie, D. A. (1986). Essentials of educational measurement (4th ed.). Englewood Cliffs, NJ: Prentice-Hall, Inc

Freudenthal, H. (1991). Revisiting Mathematics Education. Dordrecht: Kluwer Academic Publisher.

Freudenthal, H. (1999). Didactical Phenomenology of Mathematical Structures. Kluwer Academic Publisher.New York

Gravemeijer, K. (1994). Developing Realistic Mathematics Education. Utrecht: CD- $\beta$ Press.

Hadi, S. (2005). Pendidikan Matematika Realistik dan Implementasinya. Tulip: Banjarmasin

Katz, L. G. (1993). Dispositions as Educational Goals. ERIC Digest. (Online), (www.eric.ed.gov.), diakses 4 September 2016 
Kilpatrick, J., Swafford,J., \& Findell, B. (2011). Adding it up: Helping children learn mathematics. Washington DC: National Academy Press.

Lange, J. De. (1996). Using and Applying Mathematics in Education. In Bishop, A.J. et.al. International Handbook of Mathematics Education. Netherland: Kluwer Academic.

Mahmudi, A. (2010). Tinjauan Asosiasi antara Kemampuan Pemecahan Masalah Matematis dan Disposisi Matematis. (Online), (http://staff.uny.ac.id/sites/default/files/ penelitian/Ali\%20Mahmudi), diakses 4 September 2016

NCTM. (1989). Curriculum and Evaluation Standards for School Mahematics. (Online), (http://www.krellinst. org/AiS/textbook/manual/stand/CTME_stand.html),

Sugiyono. (2012). Metode Penelitian Kuantitatif Kualitatif dan R\&D. Bandung: Alfabeta.

Sopia, H.N. \& Wutsqa, D.W. (2015). Keefektifan Pendekatan Realistik ditinjau dari Prestasi Belajar, Kemampuan Pemecahan Masalah, dan Kepercayaan diri matematika. Phytagoras: Jurnal Pendidikan Matematika, 10(2), 146-154. 
